\title{
PARENTING PRACTICES AND KNOWLEDGE REGARDING THEIR CHILDREN EXPOSURE TO SMARTPHONE: A TUNISIAN SURVEY
}

\author{
$\underline{\text { H. Bachrouche }}^{1}$, F. Bouothmani ${ }^{1}$, A. Guedria ${ }^{1}$, S. Ben Amar ${ }^{1}$, K. Chraiet ${ }^{1}$, K. Aissa $^{1}$ \\ ${ }^{1}$ El Manar University - University of Medecine of Tunis - \\ Mohamed Tlatli Hospital, Pediatrics and Neonatology, Nabeul, Tunisia
}

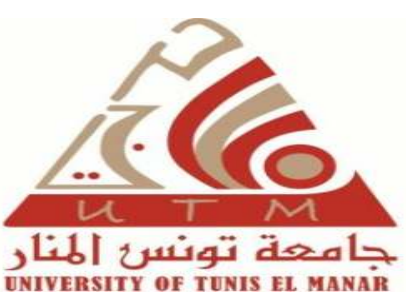

\section{Background:}

- There is a general consensus that excessive screen time has an adverse impact on childhood development.

- The current American Academy of Pediatrics (AAP) guidelines recommend that children under 2 years of age should not spend any time using electronic media, while children over 2 years of age should be restricted to less than $2 \mathrm{~h}$ per day.

Aim:

- To evaluate parenting practices regarding their children's use of smartphones and their knowledge about AAP's advice.

Methods:

We conducted a study targeting parents of children exposed to smatphones, over 3 days in April 2018 with two methods. The first was an online survey available in three languages. The second was a face to face questionnaire.

We used Khi² Test to analyze statistics with SPSS 20.0.

Results:

$>$ We collected 206 responders

$>157$ mothers and 49 fathers.

$>$ The mean maternal age $=36,8$ years

$>$ The mean paternal age $=41,8$ years

$>81 \%$ of parents had a higher level of education. (chart 1)

$\square$ Parenting Practices Evaluation:

$>$ We used 11 questions divided into 6 items (Time

Restriction, Behavioral Control, Instructive Practices, Coviewing, Planful Restriction and Reactive Content Restriction) to evaluate parenting practices.

$>$ Table 1 and 2 depicts the main results.

- Knowledge about AAP's advice Evaluation:

$>$ Table 3 depicts the main results of Knowledge evaluation.

$>$ The parents gave the correct answer when asked about: screen time recommendable for children less than 2 years, effects of screen watching on dietary habits and effects of screen viewing on children's cognitive development respectively in $71.5 \%, 59,5 \%$ and $60 \%$ of cases.

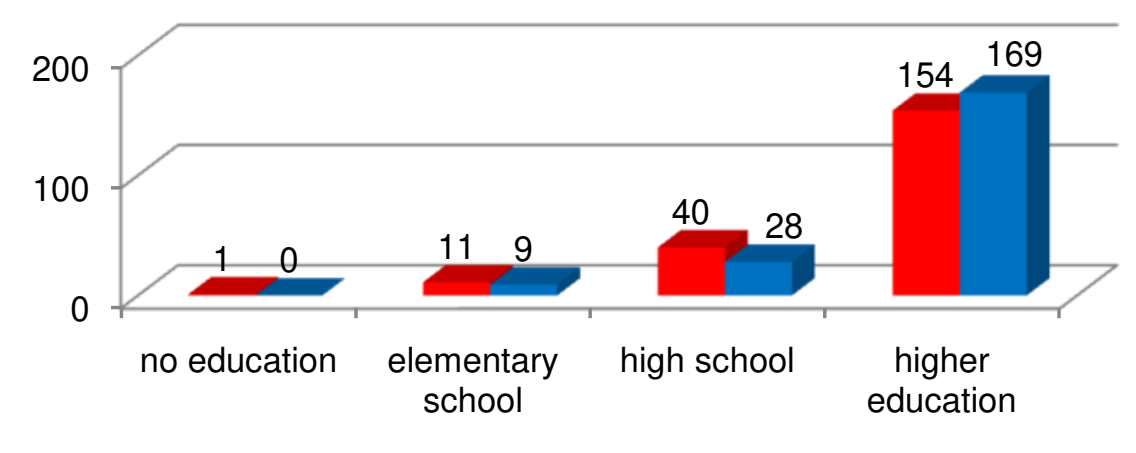

father

Chart 1: parents's education level

References

American Academy of Pediatrics. Policy statement: Children, adolescents, and the media. Pediatrics 2013; 132: 958-61. Thompson D, Johnson S, Vanderwater E, Schmiege S and al. Parenting practices regarding TV viewing in low-income Mexican American mothers of preschoolers. J Dev Behav Pediatr. 2016; 37(6):465-474.

Sophie Domingues-Montanari. Clinical and psychological effects of excessive screen time on children. Journal of Paediatrics and Child Health 53 (2017) 333-338
Correlations: Mothers were found to have more instructive practices than fathers $(p=0,008)$.

Behavioral control was associated to the father's $(p=0,048)$ and the mother's job $(p=0,041)$. A correlation was found between the job of the father and restriction viewing in reaction to inappropriate content $(p=0,01)$.

Comments:

Our results reflect the most current thinking on smartphone's practices in a high level education parents. They are essentially anxious about this exposure to smartphones and they know less about the beneficial effects. Their inhibiting practices are more pronounced than their practices favoring the benefits of smartphones.

the knowledge of parents in our study regarding AAP's advice are satisfactory.

Conclusion:

Today's children grow up immersed in digital media, which has both positive and negative effects on healthy development. Tunisian educated parents are quite aware of the harm of exposure to smartphones.

Table 1: Practices evaluation (frequency questions)

\begin{tabular}{|c|c|c|c|c|}
\hline How often do you...... & Always & Often & Sometimes & Never \\
\hline \multicolumn{5}{|l|}{ Time Restriction } \\
\hline Q1/ limit time spent on his smartphone? & 76 & 76 & 43 & 11 \\
\hline \multicolumn{5}{|l|}{ Behavior Control } \\
\hline $\begin{array}{l}\text { Q2/ encourage your child to do something positive by giving him the } \\
\text { smartphone? }\end{array}$ & 15 & 35 & 74 & 82 \\
\hline $\begin{array}{c}\text { Q10/ use the smartphone to make your child eat something he doesn't } \\
\text { like habitually? }\end{array}$ & 6 & 16 & 50 & 134 \\
\hline \multicolumn{5}{|l|}{ Instructive Practice } \\
\hline $\begin{array}{l}\text { Q3/ explain to your child the harm that can do the videos he's watching or } \\
\text { the games he's playing on his smartphone? }\end{array}$ & 89 & 70 & 34 & 15 \\
\hline $\begin{array}{l}\text { Q4/ explain to your child the benefits of the videos he's watching or the } \\
\text { games he's playing on his smartphone? }\end{array}$ & 32 & 38 & 74 & 62 \\
\hline \multicolumn{5}{|l|}{ Coviewing } \\
\hline $\begin{array}{l}\text { Q5/5. Do you watch the videos or play the games with your child on his } \\
\text { smartphone? }\end{array}$ & 17 & 43 & 112 & 34 \\
\hline \multicolumn{5}{|l|}{ Reactive Content Restriction } \\
\hline $\begin{array}{l}\text { Q7/ prohibit your child from playing a kind of games or watching a kind of } \\
\text { videos on his smartphone? }\end{array}$ & 92 & 54 & 51 & 9 \\
\hline $\begin{array}{l}\text { Q8/ stop your child from playing a game or wathing a video if you judge } \\
\text { that the content is inappropriate for them? }\end{array}$ & 144 & 26 & 22 & 13 \\
\hline
\end{tabular}

Table 2: Practices evaluation (multiple answer question)

\begin{tabular}{|l|c|c|c|c|c|}
\hline Coviewing & $\begin{array}{l}\text { To control } \\
\text { him }\end{array}$ & $\begin{array}{l}\text { To love } \\
\text { you more }\end{array}$ & $\begin{array}{l}\text { lo spend } \\
\text { more time } \\
\text { with you }\end{array}$ & $\begin{array}{l}\text { To watch videos } \\
\text { or play games } \\
\text { you like }\end{array}$ & $\begin{array}{l}\text { Other } \\
\text { reasons }\end{array}$ \\
\hline $\begin{array}{l}\text { Q6/ Why do you watch the videos or play the games with your child } \\
\text { on his smartphone? }\end{array}$ & $\mathbf{1 2 1}$ & 23 & 64 & 28 & 35 \\
\hline Planful restriction & $\begin{array}{l}\text { In the } \\
\text { morning }\end{array}$ & $\begin{array}{l}\text { During } \\
\text { meals }\end{array}$ & $\begin{array}{l}\text { Before } \\
\text { sleping }\end{array}$ & other times & \\
\hline $\begin{array}{l}\text { Q9/ Do you prohibit you child from playing with their smartphone at } \\
\text { a specific time of the day? }\end{array}$ & 80 & 120 & 118 & 35 & \\
\hline Behavior Control & $\begin{array}{l}\text { House } \\
\text { affairs }\end{array}$ & $\begin{array}{l}\text { To rest } \\
\text { after } \\
\text { work }\end{array}$ & $\begin{array}{l}\text { Finish nour } \\
\text { work at } \\
\text { home }\end{array}$ & Talk to others & $\begin{array}{l}\text { other } \\
\text { things }\end{array}$ \\
\hline $\begin{array}{l}\text { Q11/ Do you give to your child the smartphone to let yourself do } \\
\text { other things? }\end{array}$ & 43 & 64 & 38 & 55 & 70 \\
\hline
\end{tabular}

Table 3: Knowledge evaluation

\begin{tabular}{|c|c|c|c|c|c|}
\hline Time allowed for $<2$ years & Not allowed & $<1 \mathrm{~h}$ & $<2 \mathrm{~h}$ & $2-8 h$ & unlimited \\
\hline $\begin{array}{l}\text { Q12/ In your opinion how much time are the children aged below } \\
2 \text { years allowed to spend in front of screens? }\end{array}$ & 151 & 35 & 15 & 2 & 3 \\
\hline Effects of screens on eating behaviors & $\begin{array}{l}\text { Reduces she appetite } \\
\text { forall food }\end{array}$ & 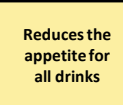 & 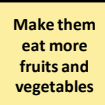 & \multicolumn{2}{|c|}{ 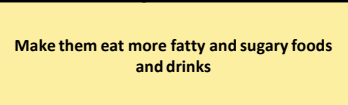 } \\
\hline $\begin{array}{l}\text { Q13/In your opinion what is the effect of screens on the eating } \\
\text { behaviors of children? }\end{array}$ & 77 & 18 & 15 & \multicolumn{2}{|c|}{123} \\
\hline Risks on the mental development and the social intelligence & $\begin{array}{l}\text { Give them the ability of } \\
\text { talking a ta a earlier age }\end{array}$ & 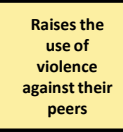 & 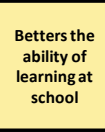 & Grows theirla & 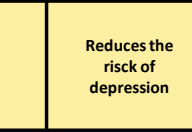 \\
\hline $\begin{array}{l}\text { Q14/ In your opinion what are the risks of screens on the mental } \\
\text { development and the social intelligence of your children? }\end{array}$ & 52 & 125 & 41 & 17 & 20 \\
\hline
\end{tabular}

